\title{
Institutional support of promising sectors of the Chechen Republic's economy
}

\author{
Tamila Tasueva, and Vera Borisova \\ Federal State Budgetary Institution of Science Complex Research Institute of the Russian Academy \\ of Sciences named after Kh.I. Ibragimov \\ Federal State-Owned Publicly-Funded Institution of Higher Education Grozny State Oil Technical \\ University named after acad. M.D. Millionshchikov, 364064, Grozny, Isaeva Ave., 100, Russia \\ Federal State-Owned Publicly-Funded Institution of Higher Education St. Petersburg State University \\ of Economics, 191023, St. Petersburg, 21 Sadovaya Street, Russia
}

\begin{abstract}
In the context of the digital transformation of the region's economy, the focus of attention of scientists and practitioners in terms of institutional changes is on rationalizing the economic relations of business entities. Institutions form the organizational-economic and regulatory-legal backbone of support for promising sectors of the economy, uniting not only social institutions, but also the structures that implement them. If laws can be changed quickly enough, informal regulations change gradually. Wherein, it is informal institutions that create the basis for evolutionary changes in legislative and regulatory rules. Nowadays, the set of regulations and means that are designed to provide institutional support to economic entities in the region is supplemented by the theme of sustainable development and the principles of environmental, resourcesaving, social and corporate cooperation (ESG, Environmental, Social, Governance). From the point of view of these principles implementation, it is assumed to create and implement the modern sustainable ecologicallyoriented ecosystem objects [1]. In our study, we proceed from the fact that the basis of the digitalization of the regional economy and its sustainable development is the institutional support of the economic system. It is the institutions that are provided with the most important role in ensuring the digital transformation of the basic sectors of the region's economy. In its turn, the digital transformation of economic sectors depends on the market potential of the infrastructure, development of financial, legal and other aspects that implement the integration relations of economic entities. Taken together, these terms determine the competitiveness of the region's economy. There is an objective need for development of theoretical and methodological provisions for formation of institutional support for the region's economy in new post-COVID normality. Special attention of the authors was focused on the study of the institutional support of the digital sector of the economy of the Chechen Republic, which is a driving force and a tool for solving a whole range of economic, social, environmental and cultural problems that are urgent in the region. This circumstance determines the relevance of this study, the significance of the tasks set and the recommendations provided.
\end{abstract}




\section{Introduction}

In the context of digital transformation and the search for ways out of the global crisis caused by the COVID-19 coronavirus pandemic, it becomes vital to combine economic thought, scientific and practical conclusions with those real processes that are taking place in the economy of the country and its regions.

The problem of the conditionality of institutional changes and economic growth is a complex and controversial socio-economic phenomenon. Laws, rules, codes and types of moral and aesthetic behavior constitute the structure of institutions. Global transformations of institutions are the result of historical transformations in the economic system that are taking place slowly. However, the greater the uncertainty and the slower institutional transformations are implemented, the higher the risk of stagnation in the economy.

Under these conditions, it is necessary to master actively the digital innovations, while avoiding mistakes in terms of institution building. The goal of institutional support for the region's economy is to ensure the sustainability and consistent reproduction of the socioeconomic integrity of the economic system, to achieve the maximum economic effect within the framework of limited resources, diverse transformations, and instability of the market environment.

The designated goal is to some extent universal for all basic institutions. Wherein, each institution performs its specific functions, in accordance with the assigned role and position on the socio-economic landscape of the region. The economic institutions under consideration form the material basis of the economic system, and the viability of the society development.

The situation is complicated by the fact that market efficiency turns out to be inadequate to social, economic and environmental efficiency [2]. A high price has been paid for "pure" market efficiency in the form of deep and often irreparable environmental destruction. Therefore, Rosprirodnadzor estimated the environmental damage from the accident in Norilsk at 148.2 billion rubles [3]. The issues of ecology, health care, science and introduction of digital innovations into economic practice have become the main agenda for development of multilateral institutions.

The coronavirus pandemic has dramatically changed the world. Many events that were expected to occur decades later took place in less than one year. The coronavirus crisis tuned the region's economy to accelerated transformation of industries and areas of activity, predetermined the need for structural changes. A situation has arisen when the established institutions must adapt as quickly as possible to the new conditions, and in a number of cases the creation of new institutions is required.

Adaptation of the institutional support of the region's economy to the new normalcy, on the one hand, opens up additional opportunities for the growth of the region's economy, but at the same time, presents new challenges to business entities. Adjustment of market behavior must penetrate all the components of new business models. [4] First of all, this is associated with construction and recovery of business after the crisis on the principles of cooperation between partners in the coordinates of digital, environmental, social and corporate interaction.

It is obvious that dynamic development of the region, an increase in production capacities, modernization of production processes, increase in export-import opportunities largely depends on the driving industries. This article presents the results of the study of the institutional support of promising sectors of the economy of the Chechen Republic. The authors' attention is focused on the digital sector of the republic's economy and the assessment of the prospects for its development. 


\section{Research Methodology}

The methodological basis for the disclosure of the problem under study is consideration of the economy of the Chechen Republic in the context of the institutional support of the digital sector as a driver of innovative transformations in the economic system of the region. Identification of the features of the emergence and functioning the digital innovations in the economy of the Chechen Republic was carried out on the basis of the scientific groundwork formed to date [5-7], use of methods of institutional design, stratification and focus group analysis [8-10].

The study was based on the Legislative acts and policy documents on development of the digital sector of the economy in Russia and its regions, the provisions set out in the Strategy for the socio-economic development of the Chechen Republic until 2035, research materials on institutional development, the concept of sustainable development and environmental conservation [11- 16]. Study conclusions regarding the institutional support of promising sectors of the regional economy are formed on the basis of generalizing the existing practices and theoretical views on formation of a new institutional framework of infrastructure in the digital economy of the region [17-20]. The set of analytical conclusions based on the above scientific basis determines the author's position and the theoretical and applied significance of the problem under study.

\section{Research Results}

The socio-economic development of the modern region is determined by the level of digitalization of the areas of its economy and the society life-sustaining activity. The mission of the digital economy formation in the Chechen Republic is defined by the Strategy of its socio-economic development until 2035. Due to digitalization, it is planned to ensure the quality of life of citizens, increase the competitiveness and security of the region's economy, and in the future - to form an independent competitive digital industry in the republic.

Problems of sustainable development have become the agenda of multilateral institutions in the world and in Russia. In our study, we relied on the basic provisions of the concept of sustainable development, the recommendations provided in the "Strategy for the socio-economic development of the Chechen Republic until 2035".

The study found that the priorities, goals and objectives of the state administration of the Chechen Republic are consistent with the basic provisions of the concept of sustainable development and the principles of ecological, environmental, socially-oriented cooperation of partners (ESG, Environmental, Social, Governance). The state governing bodies of the republic have to deal with a group of various parties, including investors, business entities, public organizations and other structures, the balance of interaction between which is quite difficult to find. The best way to measure progress that the authorities can use is summarized in the fourth edition of the Strategy. Formation of institutional and infrastructural conditions for development of the digital sector in the region's economy are among the targeted results outlined by the leadership of the republic.

Development of recommendations regarding implementation of institutional adjustments in the regional economy was preceded by a comprehensive analysis of the challenges and opportunities for digitalization. Table 1 shows the results of this paper on the example of the Chechen Republic [11]. 
Table 1. Results of the SWOT matrix (strengths and weaknesses of the economy of the Chechen Republic).

\begin{abstract}
Strengths
A good managerial groundwork in the regional leadership of the republic, the ability of personnel to carry out large-scale transformations in strategically important sectors; favorable natural and climatic resources for development of the agro-industrial complex, tourism; availability of mineral raw materials for production of building materials and development of the construction industry; good provision of hydro and geothermal resources for energy development.
\end{abstract}

\section{Possibilities}

Development of interregional network communities and forms of communication with them. Interregional exchange and export of agricultural products. Development and implementation of new instruments of publicprivate partnership, entrepreneurial potential and interregional innovation projects. Improving the quality of banking and insurance products as part of creating a digital system in the fintech finance sector and realizing the potential of the capital of the Republic, Grozny - the driver of the region's economy.

\begin{abstract}
Weaknesses
Insufficient development of institutions that facilitate interaction between the state, private business and science. High subsidization of the region with a shortage of financial resources. Lack of subjects that are drivers of socioeconomic development and insufficient information integration of business entities. Weak level of competition and entrepreneurial initiatives, low labor productivity with a significant share of the shadow economy and the informal sector.
\end{abstract}

Experts note that further development of the Chechen Republic is impeded by a set of interrelated problems, including: lack of factors contributing to economic development; low level of development of sectors that are drivers of the economy; predominance of the public sector in the overall structure of the economy (the share of the public sector is $16.5 \%$ ); low level of labor productivity (35\% lower than the average for the North Caucasian Federal District); weak level of competition and entrepreneurial initiatives [21].

The analysis showed that institutional and infrastructural problems affect the creation of quality jobs and the level of their accessibility for young people. The consequence of this is structural imbalances in the economy of the republic and low competitiveness.

The analytical review prepared for the fourth edition of the program of strategic socioeconomic development of the Chechen Republic until 2035 noted that the structure of the economy of the Chechen Republic remains uncompetitive. In 6 of the 14 key sectors of the economy, the Chechen Republic lags far behind in productivity. Therefore, in the "Mining" sector, productivity in the Chechen Republic in 2015 amounted to 739 thousand rubles/person compared to 3,764 thousand rubles/person on average for Russia, in the energy sector, respectively, - 497 and 993 thousand rubles/person, in the "Transport and Communications" sector - 494 and 929 thousand rubles/person, in the "Manufacturing" sector - 171 and 905 thousand rubles/person, in the "Agro-Industrial Complex" sector 138 and 565 thousand rubles/person, in the "Finance" sector - 54 and 128 thousand rubles/person" [21].

Among the reasons for this state of affairs, experts name the following: depreciation of fixed assets and depletion of wells in resource extraction and in the energy sector; limited logistics schemes for goods movement in view of a small internal market and 
underdevelopment of interregional trade; weak integration of the industrial and agricultural sectors of the economy; lack of modern banking and insurance products. This situation negatively affects the investment attractiveness of the republican economy. Investors interested in access to natural resources need institutional support, provision of modern infrastructure, digital products and services.

We have highlighted the weaknesses and threats to development of the regional economy allow us to identify the following urgent problems:

- insufficient financing of development of subjects that are drivers of socio-economic development and weak information integration of business entities;

- weak level of technical and process development of the digital sector of the republic's economy;

- insufficient introduction of the mechanism of public-private partnership and crossfunctional management methods into economic practice;

- underdeveloped transport and logistics infrastructure;

- lack of competition among business structures and a high share of the informal sector of the economy.

Solution of these problems predetermines the need for further analysis of the institutional support for the digital economy of the region as a backbone factor.

\section{Discussion of Study Results}

Development of promising sectors of the Chechen Republic's economy (agro-industrial complex, construction, tourism, digital economy, transport, logistics, healthcare, education) has always been in the center of attention of the leadership and the scientific community of the region. Let's pay attention to the digital sector of the Chechen Republic's economy.

The strategic task has been set to significantly increase the contribution of the digital industry to the gross regional product of the republic and increase the number of participants in this sector, as well as to develop the export of information and communication technologies, products and services. In the future, on the basis of the Chechen Republic, it is planned to develop and introduce a cross-channel information system for the credit and financial sector of the North Caucasus Federal District.

The subject-object composition of the digital sector of the Chechen Republic's economy is characterized by: suppliers of digital products and services; infrastructure; human resources; integration links of business partners and the overall development of the digital environment.

Development and production of digital products and services is aimed at servicing information and telecommunications infrastructure in the state, industrial and consumer segments. Key participants: external IT companies, Technopark of the Chechen State University, State Unitary Enterprise Center for Information Technologies.

Among the barriers to achieving these goals, experts note: "the lack of its own IT companies and effective demand for digital products and services in the republic, as well as low digital literacy of the population" [11].

Another problem of the progressive development of the digital sector of the Republic is insufficient level of its infrastructural support. Participants of the infrastructure digital subsector: MTS, Megafon, Beeline, Vainakhtelecom, note that infrastructure development is hampered by: "low 4G coverage (only the central part of the Republic is covered); insufficient quality and coverage of cellular GSM communication; lack of effective monitoring of network performance by telecom operators and modern infrastructure for storing and processing data; insufficient level of security of data transmission and storage in the public sector" [11]. 
An important factor in development of the digital sector of the economy is its staffing. Training of highly qualified specialists for the digital economy in the Republic is carried out not only by higher educational institutions. The digital environment and business climate of the Chechen Republic includes "specialized platforms for IT companies; institutions for the development and support of startups; regulatory services and institutions for the protection of intellectual property. Key players in the digital environment: the Government of the Chechen Republic, the Ministry of Transport of the Chechen Republic, Technopark of the Chechen State University. Among the barriers to development of the IT sector, there are limitations associated with development of an innovative business climate; weak motivation of investors and large IT companies; insufficient number of business incubators, accelerators and venture funds; lack of support for commercialization of IT products (including registration of patents for IT startups); high monopoly prices for cable broadband Internet" [11].

Wherein, it can be noted that certain prospects for development have emerged in the digital economy of the Chechen Republic. According to experts, they are associated with an increase in digital transformations in the state and social sectors of the region's economy, in healthcare and education institutions, in creation of state registries and use of blockchain technology. "One of the largest fiber-optic networks in Russia in terms of density operates throughout the territory of the Chechen Republic. 4G mobile communications are deployed in the central part of the Republic. New Veduchi ski resort is provided with $4 \mathrm{G}$ communication and cable high-speed Internet. There is one local operator Vainakhtelecom and all major federal operators (Megafon, MTS, VimpelCom) in the region."

"Another opportunity for innovative development is formation of digital skills among the population of the Chechen Republic, the use of new online services. The city of Grozny has chosen the digital format of urban management and transport logistics ("smart city") is incorporated in the concept of development of the city of Grozny.

Among the target results of digitalization of the republican economy, the following are indicated: further development of information and communication technologies in the public sector, health care and education, including the potential of the Chechen State University, Grozny State Oil Technical University named after acad. M.D. Millionshchikov; creation of key growth points based on big data, introduction of blockchain technology in the agro-industrial complex, construction, finance and credit and logistics.

The leadership of the republic has set ambitious tasks - achieving leadership in the field of digitalization in the regional market; "export of digital products and services, development of the regional center of digital competencies, IT infrastructure operating throughout the North Caucasus Federal District. Joint efforts of the state and business in this direction are concentrated on interaction with international partners; support of companies exporting IT products and services; creation of mechanisms for preservation of successful IT startups in the territory of the republic; building a flagship IT educational institution; modernization of the previously created IT infrastructure" [11].

In the Chechen Republic digital economy sector, it is planned to create levels of interaction between business entities and the Ministry of Digital Development and Public Administration. According to the results of the focus group survey conducted within the framework of this study, a "digital valley" in the republic is singled out among the visible effects of the institutional provision of infrastructure.

According to forecasted estimates of experts, "the share of products of IT companies in the export structure in the next five years will reach $1.5 \%$, more than 1000 IT startups will be launched; coverage of the region with broadband internet will be $100 \%$.

Investments in these digital initiatives are provided at the expense of federal and regional budget funds, as well as at the expense of Russian and foreign partners of digital 
transformation (Sberbank PJSC, Yandex LLC, Abu Dhabi Development Fund), funds of non-profit organizations. Such cooperation presupposes the development of environmental institutional conditions: of legislative, regulatory, informational, infrastructural, and personnel nature.

On the regional digital institutional landscape, the prerequisites for networked cooperation of partners have emerged. This is the interaction of participants in interregional cooperation within the framework of digital platforms, "joint use of marketing and advertising programs by partners; business inter-network communication; promotion of joint interregional brands" [11]. Higher educational institutions of the Chechen Republic and the campus of the Chechen State University as a communicative environment for interaction of doctoral students, teachers and researchers can act as the initiator and coordinator of the activities of the participants of the digital platform." The problem of creating infrastructure to ensure universal access to digital services is related to the issue of institutional support for infrastructure development. Primary one is the infrastructure development itself, as a condition for creating the possibility of digital transformation of the region's economy. From the point of view of creation and development of the modern infrastructure of the region, the latest technologies and tools are necessary to improve the level of its quality.

\section{Conclusion}

Therefore, we approached the analysis and assessment of the institutional support of the region's economy critically, considering both the strengths and weaknesses of the ongoing transformations. We concluded that the institutional support of the digital economy in the Chechen Republic has growth potential, primarily in the state and social sectors of the economy. This determines the feasibility of formation and development of the ecosystem of the Republic's digital economy aimed at achieving synergy of cross-channel cooperation of its participants. Institutional support for promising sectors of the region's economy plays a key role among the factors contributing to formation of the digital economy ecosystem.

\section{Acknowledgment}

The article was prepared with the financial support of the Russian Foundation for Basic Research (project No. 20-010-00141/20 "Formation of the institutional framework of the regional infrastructure in the digital economy". "The reported study was funded by RFBR, project number 20-010-00141\20").

\section{References}

1. V. Borisova, T Tasueva, European Proceedings of Social and Behavioural Sciences EpSBS, 230 (2021)

2. O. V. Trofimov, V. Ya. Zakharov, V. G. Frolov, Bulletin of the Nizhny Novgorod University named after N.I. Lobachevsky. Series. Social sciencies., 4(56), 43 (2019)

3. Interfax 2020, https://www.rbc.ru

4. V. Borisova, M. Bilczak, Olsztyn Economic Journal (uwm.edu.pl) 15(3) (2020)

5. A. A. Auzan. World Economy and International Relations, 61(10), 96 (2017)

6. A. E. Shastitko, Problems of Economics, 8 (2016)

7. D. North, Institutions, Institutional Changes and Economic Performance, 17 (1997) 
8. V. V. Borisova. Bulletin of the St. Petersburg State University of Economics, 2(120), $86(2020)$

9. V. V. Borisova, T. S. Tasueva, B. K. Rakhimova, Lecture Notes in Networks and Systems, 91, 631 (2020)

10. V. V. Borisova, K. G. Gordei, Science of the XXI century: problems and prospects of researches, 2, 3 (2017)

11. Strategy for the socio-economic development of the Chechen Republic until 2035, https://economy-chr.ru

12. L. M. Grigoriev, I. A. Makarov, A. K. Sokolova, V. A. Pavlyushina, I. A. Stepanov, Bulletin of international organizations, 15(1) (2020)

13. I. A. Makarov, I. A. Stepanov, Bulletin of Moscow University, Series 6: Economics, 6 (2017)

14. V. I. Danilov-Danilyan, Bulletin of the Russian Academy of Sciences, 4 (2013)

15. Higher School of Economics Report "Turn to Nature: Russia's New Environmental Policy in the Context of Green Transformation of the World Economy and Politics: A Report on the Results of a Series of Situational Analysis, 97 (2021)

16. On the state and protection of the environment of the Russian Federation in 2019. State report. M.: Ministry of Natural Resources of Russia; Moscow State University named after M.V. Lomonosov (2020)

17. N. A. Osintsev, E. V. Kazarmshchikova. Factors of sustainable development of transport and logistics systems. SPTKR, 1 (2017)

18. I. G. Rzun, N. O. Starkova, Bulletin of NGIEI, 11, 89 (2016)

19. A. D. Moiseev, I. F. Narizhny. Central Scientific Bulletin Magazine, 19(36)-2 (2017)

20. V. V. Borisova, Bulletin of the Russian State Economic University (RINKh), 2, 45 (2020)

21. T. S. Tasueva, V. V. Borisova, Bulletin of GGNTU. Humanities and socio-economic sciences, 16-4(22), 15 (2020)

22. Indicators of social and economic development of the Chechen Republic, https://economy-chr.ru 